\title{
Concave Rot of Melon Fruit Caused by Two Phomopsis Fungi
}

\author{
Takashi OHSAWA* and Takao KoBAYASHI**
}

\begin{abstract}
Many isolates belonging to the genus Phomopsis were obtained from the concave rot of melon fruit, Cucumis melo, a new postharvest disease. They were divided into four groups of A, B, C and D according to their cultural characters on PSA. Several representative isolates selected from each type of isolates showed clear pathogenicity to melon fruits. Morphologically, isolates were divided into two groups; one having shorter $\beta$-conidia and containing colony groups of $\mathrm{A}$ and $\mathrm{B}$, and the other having longer $\beta$-conidia and containing colony groups $\mathrm{C}$ and $\mathrm{D}$. Some isolates of the former group produced perithecial stage on PSA and also on water agar plate containing a fragment of melon fruit. A new variety of Diaporthe melonis Beraha et O'Brien, D. melonis var. brevistylospora Kobayashi et Ohsawa was proposed for the fungus. Although the isolates of the latter did not produce any perithecia on artificial media mentioned above, these were identified as the conidial stage of Diaporthe melonis Beraha et O'Brien var. melonis, Phomopsis cucurbitae McKeen sensu Behara et O'Brien.
\end{abstract}

(Received January 5, 1989)

Key words: concave rot, melon fruit, postharvest disease, Diaporthe melonis var. brevistylospora, Phomopsis cucurbitae, Phomopsis brevistylospora.

\section{INTRODUCTION}

Since 1981, occurrence of a new postharvest disease of netted melon (Cucumis melo L.), which was harvested at greenhouses in Shizuoka Prefecture, was frequently noticed in the markets. The disease was characterized by making round concave on fruit surface, and a lot of Phomopsisisolates were obtained from the rotted fruits at high rate.

The present paper deals with the diagnose of the disease, isolation of associated fungi from the diseased fruits, pathogenicity of Phomopsis-isolates, and morphology and taxonomy of the causal Phomopsis. Parts of the result were preliminarily and orally published ${ }^{2,3)}$.

\section{DISEASE}

\section{Symptoms and disease occurrence}

The disease usually begins to form small round patches on the surface of fruits 7 to 10 days after harvesting and marketing. These patches are at first $2 \sim 7 \mathrm{~mm}$ in diameter and watersoaked pale green in color, then enlarge to $20 \sim 60 \mathrm{~mm}$ in diameter and produce somewhat sunken concaves just beneath the netty ornament of fruit surface (Fig. 4, A C). Diseased fruits become soft and rotten, although no hyphae and mycelia are recognized externally on them.

Questionnaires concerning with the occurrence of the concave rot of melon fruits, at markets

* Shizuoka Prefectural Agricultural Experiment Station, Toyoda-cho, Iwata-gun, Shizuoka 438, Japan 静岡県農業試験場

** Forestry and Forest Products Research Institute, Kukisaki-cho, Inashiki-gun, Ibaraki 305, Japan 森林総合研究所 
in Tokyo and Osaka, were collected in 1985 from 16 wholesalers and the result was given in Fig. 1. The occurrence of concave rot of melon fruit was frequently recorded on the fruits brought to the markets from June through October. Close relation between cloudy and rainy weather during the period of net formation and high frequency of disease occurrence was noted. However, it is quite difficult to diagnose the disease appearance before marketing, because any abnormal symptoms could not be recognized on the fruit surface just after harvesting.

\section{CAUSAL FUNGI}

\section{Isolation of associated fungi}

Isolation tests from the rotted patches of fruits were repeatedly carried out from 1981 to 1985. Small pieces obtained from the diseased skin were placed onto potato-sucrose agar (PSA) plate after surface sterilization by $80 \%$ ethanol. The plates were kept for about 10 days at $25 \mathrm{C}$. Hyphae grown from the diseased tissue were transplanted to PSA slants and again kept in an incubator regulated at $25 \mathrm{C}$.

As shown in Table 1, total 66 diseased fruits were used for isolation experiments. Out of 79 isolates obtained, $77(97 \%)$ belonged to the genus Phomopsis, and remaining $2(3 \%)$ did to the genus Fusarium. Based on the growth type of colonies on PSA plate, these Phomopsisisolates were divided into 4 groups. Isolates called group A developed flat and radial mycelial colonies. Colony of group B-isolates was similar to that of group A but had more hairy to fibriform aerial mycelia than the latter. Isolates belonging group $\mathrm{C}$ formed slightly zonate colonies. Colony of group D-isolates showed distinctly concentric zones (Fig. 4, D G). Group A- and D-isolates accounted for $54 \%$ and $29 \%$ of 79 isolates, respectively. Isolation rates of group B- and C-isolates were relatively low.

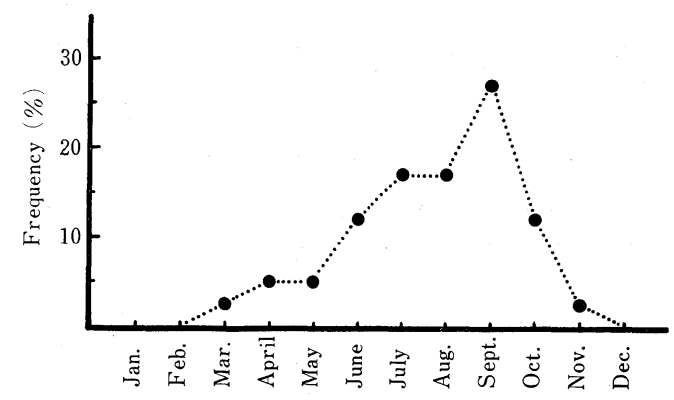

Fig. 1. Frequency of monthly record on the occurrence of concave rot of melon fruits in 1985.

Table 1. Isolation of fungi from concave rot lesions of melon fruits

\begin{tabular}{|c|c|c|c|c|c|c|c|c|}
\hline \multirow{2}{*}{ Year } & \multirow{2}{*}{$\begin{array}{l}\text { Fruit } \\
\text { tested }\end{array}$} & \multirow{2}{*}{$\begin{array}{l}\text { Lesion } \\
\text { isolated }\end{array}$} & \multirow{2}{*}{$\begin{array}{c}\text { Isolates } \\
\text { obtained }\end{array}$} & \multicolumn{4}{|c|}{ Phomopsis ${ }^{\text {a) }}$} & \multirow{2}{*}{ Fusarium } \\
\hline & & & & A & B & $\mathrm{C}$ & $\mathrm{D}$ & \\
\hline 1981 & 8 & 8 & 8 & 6 & 0 & 0 & 2 & 0 \\
\hline 1982 & 6 & 6 & 6 & 3 & 0 & 0 & 3 & 0 \\
\hline 1983 & 13 & 13 & 15 & 10 & 0 & 0 & 3 & 2 \\
\hline 1984 & 22 & 22 & 22 & 10 & 1 & 1 & 10 & 0 \\
\hline 1985 & 17 & 28 & 28 & 14 & 5 & 4 & 5 & 0 \\
\hline Total & 66 & 77 & 79 & 43 & 6 & 5 & 23 & 2 \\
\hline Percentage & & & 100 & 54 & 8 & 6 & 29 & 3 \\
\hline
\end{tabular}

a) Growth type of colony $=\mathrm{A}$ : flat, B: hairy, C: slightly zonate, D: concentric. 


\section{Pathogenicity of Phomopsis-isolates}

To confirm the pathogenicity of the Phomopsis-isolates obtained to melon fruits, several inoculation tests were conducted. The first inoculation series were planned to clear the time of infection concerning with the different growth stages of fruit. Selected 8 isolates consisting of 5 of group A (S-1, 4, 6, 8 and 61) and 3 of group D (S-2, 7 and 69) were used as inoculum. Each of fruits at the different growth stage was wounded 1,3 or 5 portions with a sterilized knife and inoculated with a piece of colony of the isolate at each wound. They were then covered individually with a polyethylene bag which was removed after 3 days. Immature inoculated fruits growing on vines were kept in greenhouse until their maturity. After harvest, the fruits were placed on the experimental bench in laboratory and disease development was continuously observed. Fruits inoculated after harvesting, were also kept in laboratory to observe the appearance of the disease. Fruits used for the control were treated as same as to those for inoculation except the usage of agar piece instead of fungus inoculum.

Results were given in Table 2. In every cases of inoculation against the fruits before harvest, no disease development was observed until the optimal harvesting time. Lesions developed on all inoculated fruits within 3 to 10 days after harvest, and patches of typical concave rot were produced on them. No relations between the time of inoculation to the fruit, in other words, between growth stage of fruit inoculated and time and rate of disease development were recognized. Of course, inoculation to the harvested fruits was succeeded at a high rate. Generally, it might be said that the pathogenicity of the Phomopsis-isolates belonging growth type $A$ and $\mathbf{D}$ was not different from each other.

The second inoculation series was planned to confirm the pathogenicity of Phomopsis-isolates belonging to every growth type of culture. Method of inoculation was the same as that in the first series. Three points on a fruit were wounded and inoculated with an isolate. In total 35 isolates were used in this test. Result was given in Table 3. Every growth types of

Table 2. Inoculations of melon fruits at different growth stages with Phomopsis-isolates from concave rot of melon fruit

\begin{tabular}{|c|c|c|c|c|c|c|c|c|c|}
\hline \multirow{3}{*}{$\begin{array}{l}\text { Year } \\
1982\end{array}$} & \multirow{2}{*}{\multicolumn{2}{|c|}{$\begin{array}{c}\text { Date of } \\
\text { inoculation }\end{array}$}} & \multirow{2}{*}{$\begin{array}{l}\text { Growth } \\
\text { type of } \\
\text { colony }\end{array}$} & \multirow{2}{*}{$\begin{array}{l}\text { Number } \\
\text { of isolate } \\
\text { used }\end{array}$} & \multirow{2}{*}{\multicolumn{2}{|c|}{$\frac{\text { Fruits Wounds }}{\text { inoculated }}$}} & \multicolumn{2}{|c|}{ Diseased fruits } & \multirow{2}{*}{$\begin{array}{l}\text { Lesions } \\
\text { developed }\end{array}$} \\
\hline & & & & & & & \multirow{2}{*}{$\begin{array}{c}\text { before harvest } \\
0\end{array}$} & \multirow{2}{*}{$\begin{array}{c}\text { after harvest } \\
9(75 \%)\end{array}$} & \\
\hline & July & $1^{\text {a) }}$ & $\mathrm{A}$ & 4 & 12 & 36 & & & $25(69 \%)$ \\
\hline & & & $\mathrm{D}$ & 1 & 2 & 6 & 0 & $2(100)$ & $6(100)$ \\
\hline & & & Control & - & 3 & 9 & 0 & $0(0)$ & $0(0)$ \\
\hline & July & $14 b)$ & A & 4 & 12 & 60 & 0 & $9(75)$ & $45(75)$ \\
\hline & & & $\mathrm{D}$ & 2 & 6 & 30 & 0 & $3(50)$ & $15(50)$ \\
\hline & & & Control & - & 3 & 15 & 0 & $0(0)$ & $0(0)$ \\
\hline \multirow[t]{6}{*}{1983} & Sept. & $9^{c)}$ & A & 3 & 18 & 18 & 0 & $8(44)$ & $8(44)$ \\
\hline & & & $\mathrm{D}$ & 1 & 6 & 6 & 0 & $3(50)$ & $3(50)$ \\
\hline & & & Control & 一 & 6 & 6 & 0 & $0(0)$ & $0(0)$ \\
\hline & Sept. & $24 \mathrm{~d})$ & A & 3 & 18 & 18 & 0 & $2(11)$ & $2(11)$ \\
\hline & & & D & 1 & 6 & 6 & 0 & $3(50)$ & $3(50)$ \\
\hline & & & Control & - & 6 & 6 & 0 & $0(0)$ & $0(0)$ \\
\hline \multirow[t]{3}{*}{1982} & July & $2^{e)}$ & A & 4 & 8 & 40 & - & $5(63)$ & $19(48)$ \\
\hline & & & D & 1 & 1 & 5 & - & $1(100)$ & $5(100)$ \\
\hline & & & Control & - & 2 & 10 & - & $0(0)$ & $0(0)$ \\
\hline \multirow[t]{3}{*}{1986} & June & $18^{e)}$ & A & 3 & 6 & 18 & - & $6(100)$ & $16(89)$ \\
\hline & & & $\mathrm{D}$ & 2 & 4 & 12 & - & $4(100)$ & $10(83)$ \\
\hline & & & Control & - & 2 & 6 & - & $0(0)$ & $0(0)$ \\
\hline
\end{tabular}

a) Twenty-eighth day after pollination; late stage of net formation, b) Forty-first day after pollination; after net formation, c) Seventeenth day after pollination; early stage of net formation, d) Thirty-second day after pollination; after net formation, e) Just harvested. 
Phomopsis-isolates could develop the concave rot lesions on melon fruits after harvesting, on which inocula were placed on wounded skins at the net formation stage.

The third inoculation series were carried out to confirm the pathogenicity of Phomopsisisolates against the other parts of melon besides fruits. Seven isolates consisting of 5 of group A (S-1, 4, 6, 8 and 61) and 2 of D (S-7 and 69) were used in this experiment. Result were shown in Table 4. Isolates of Phomopsis originated from melon fruits could not develop any spot on leaves even though through wound, and on sound vines. They could develop necrotic lesions only when they were inoculated through the cut end of vines or petioles.

From these inoculation experiments, it must be emphasized that most isolates of Phomopsis obtained from the concave rot of melon fruits showed definite pathogenicity to melon fruits with no relation to the different growth type of colonies, and that they could infest the melon fruit before harvest, probably during the net formation stage, and develop the concave rot after harvest (Fig. 5, A-C).

\section{Productivity of pycnidial and perithecial stages on culture of Phomopis-isolates}

All Phomopsis-isolates obtained from the concave rot of melon fruits were cultured on PSA plates under black light blue fluorescent lamp (BLB) for one month. All isolates produced $\alpha$-conidia and 33 isolates out of 40 produced $\beta$-conidia as shown in Table 5 and Fig. 5, G and $\mathrm{H}$. Among 20 isolates of group A examined 17 isolates produced perithecial masses with black long beaks and only 2 (S-61 and 70) could produce mature asci and ascospores assigned to those of the genus Diaporthe (Fig. 5, D-F).

Besides PSA, water agar plate containing a piece of melon fruit were also used for the experiment to produce pycnidia and perithecia. These plates were irradiated BLB for one month. Among many isolates forming perithecial masses, 4 (S-61, 64, 65 and 75) produced mature asci and ascospores of Diaporthe on this medium. All isolates of Phomopsis producing mature perithecia on agar media belonged to the group A based on the growth type of colony (Table $5)$.

Table 3. Inoculation of melon fruits at the net formation stage ${ }^{\text {a) }}$ with Phomopsis-isolates from concave rot of melon fruits

\begin{tabular}{ccccccc}
\hline \multirow{2}{*}{$\begin{array}{c}\text { Growth type } \\
\text { of colony }\end{array}$} & \multicolumn{2}{c}{ Isolates } & & $\begin{array}{c}\text { Wounds } \\
\text { inoculated }\end{array}$ & & \multicolumn{2}{c}{ Lesions developed } \\
\cline { 2 - 3 } & used & positive & & & before harvest & after harvest b) \\
\hline A & 17 & $10(59 \%)$ & 51 & $0(0 \%)$ & $18(35 \%)$ \\
B & 6 & $5(83)$ & 18 & $5(28)$ c) & $12(67)$ \\
C & 4 & $4(100)$ & 12 & $0(0)$ & $9(75)$ \\
D & 8 & $4(50)$ & 24 & $0(0)$ & $9(38)$ \\
Control & - & - & 6 & $0(0)$ & $0(0)$ \\
\hline
\end{tabular}

a) May 20, 1986; 20th day after pollination, b) Period from harvest to disease development was recorded from 5 to 10 days. c) Lesions developed in greenhouse.

Table 4. Pathogenicity of Phomopsis-isolates from concave rot of melon fruits to cut vines of melon ${ }^{\text {a) }}$

\begin{tabular}{|c|c|c|c|c|c|}
\hline \multirow{2}{*}{$\begin{array}{l}\text { Growth type } \\
\text { of colony }\end{array}$} & \multicolumn{2}{|c|}{ Leaf $b), c)$} & \multirow{2}{*}{$\begin{array}{c}\text { Vine } \\
\text { unwounded }\end{array}$} & \multicolumn{2}{|c|}{ Cut end of } \\
\hline & unwounded & wounded d) & & petiole $^{c}$ ) & $\left.\operatorname{vine}^{b}\right), c$ ) \\
\hline $\mathrm{A}$ & - & - & - & $t^{\theta)}$ & $+\sim++$ \\
\hline D & - & - & - & + & $+\sim+t$ \\
\hline Control & - & - & - & - & - \\
\hline
\end{tabular}

a) Piece of colony was used as an inoculum, b) July 6, 1982, c) Sept. 21, 1988, d) Ten pin holes per one leaf were inoculated, e) + : Browning, ++ : strongly browning. 
Table 5. Conidium and ascospore productivity on artificial media in Phomopsis-isolates from concave rot of melon fruits

\begin{tabular}{|c|c|c|c|c|c|c|c|}
\hline \multirow{3}{*}{$\begin{array}{l}\text { Growth } \\
\text { type of } \\
\text { colony }\end{array}$} & \multirow{3}{*}{$\begin{array}{l}\text { Number } \\
\text { of } \\
\text { isolates } \\
\text { used }\end{array}$} & \multicolumn{4}{|c|}{ Productivity of conidia on } & \multirow{2}{*}{\multicolumn{2}{|c|}{$\begin{array}{l}\text { Productivity of } \\
\text { ascospore on }\end{array}$}} \\
\hline & & \multicolumn{2}{|c|}{ WA-Fruit $^{\text {a) }}$} & \multicolumn{2}{|c|}{ PSA } & & \\
\hline & & $\alpha$ & $\beta$ & $\alpha$ & $\beta$ & WA-Fruit & PSA \\
\hline A & 20 & 20 & 18 & 19 & 17 & 4 & 2 \\
\hline $\mathrm{B}$ & 6 & $\begin{array}{c}(++\sim++) \\
6 \\
(++\sim+++)\end{array}$ & $\begin{array}{c}(+\sim+++) \\
1 \\
(+)\end{array}$ & $\begin{array}{c}(+\sim++) \\
6 \\
(+++)\end{array}$ & $\begin{array}{c}(+\sim+t) \\
4 \\
(+)\end{array}$ & 0 & 0 \\
\hline $\mathrm{C}$ & 4 & $\begin{array}{c}4 \\
(++t)\end{array}$ & $\begin{array}{c}0 \\
(-)\end{array}$ & $\begin{array}{c}2 \\
(+++)\end{array}$ & $\begin{array}{c}1 \\
(+)\end{array}$ & 0 & 0 \\
\hline $\mathrm{D}$ & 10 & $\begin{array}{c}10 \\
(+++)\end{array}$ & $\begin{array}{c}10 \\
(+\sim+++)\end{array}$ & $\begin{array}{c}8 \\
(+++)\end{array}$ & $\begin{array}{c}4 \\
(+\sim++)\end{array}$ & 0 & 0 \\
\hline Total & 40 & 40 & 29 & 35 & 26 & 4 & 2 \\
\hline
\end{tabular}

a) Water agar with a piece of fruit, b) - : none, + : a few, $++:$ many, +++ : abundant.

Table 6. Sizes of $\alpha$ - and $\beta$-conidia in each group of Phomopsis-isolates from melon fruit

\begin{tabular}{cccc}
\hline $\begin{array}{c}\text { Growth type } \\
\text { of colony }\end{array}$ & $\begin{array}{c}\text { Number of } \\
\text { isolates } \\
\text { measured }\end{array}$ & $\begin{array}{c}\alpha \text {-conidium }(\mu \mathrm{m}) \\
\text { (average) }\end{array}$ & $\begin{array}{c}\beta \text {-conidium }(\mu \mathrm{m}) \\
\text { (average) }\end{array}$ \\
\hline $\mathrm{A}$ & 10 & $5 \sim 9 \times 1.5 \sim 3$ & $10 \sim 23 \times 0.7 \sim 1.3$ \\
& & $(6.4 \times 2.1)$ & $(16.6 \times 0.9)$ \\
$\mathrm{B}$ & 4 & $4.5 \sim 9.5 \times 1 \sim 2$ & $10 \sim 20.5 \times 0.8 \sim 1.1$ \\
$\mathrm{C}$ & 2 & $(6.4 \times 1.5)$ & $(14.5 \times 0.7)$ \\
& \multirow{2}{*}{2} & $(6.4 \times 1.7)$ & $14 \sim 27 \times 0.5 \sim 1.1$ \\
$\mathrm{D}$ & 7 & $4 \sim 9 \times 1 \sim 3$ & $(20.2 \times 0.8)$ \\
& & $(6.1 \times 2.0)$ & $16 \sim 34 \times 0.6 \sim 1.8$ \\
\end{tabular}

\section{Morphology of the causal fungus}

Morphological characteristics of pycnidial stage of Phomopsis-isolates causing concave rot of melon fruits were examined. Fruits bodies produced in the previous experiments (Table 5) were observed and their spore sizes were measured. Natures of pycnidia and stroma were not different among 4 groups of isolates. Sizes of their $\alpha$ - and $\beta$-conidia were shown in Table 6 and Figs. 2 and 3. No difference in the size and shape of $\alpha$-conidium was recognized among 4 groups of Phomopsis-isolates (Table 6, Fig. 2). However, in sizes of $\beta$-conidium isolates were divided into two groups. Sizes of $\beta$-conidia of the isolates belonging to the groups A and $\mathrm{B}$ were definitely shorter than those of isolates belonging to the groups $\mathrm{C}$ and $\mathrm{D}$ (Table 6, Fig. 3).

Dimensions of perithesial and pycnidial stages in 4 Diaporthe specimens produced on artificial media are given in Table 7. No critical difference was recorded in their sizes of asci, ascospores, $\alpha$-conidia and $\beta$-conidia among 4 isolates producing both of Diaporthe and Phomopsis stages. This is reasonable, because all isolates maturing Diaporthe stage belonged to the same group in their growth type of colony.

\section{IDENTIFICATION AND DESCRIPTION}

Taxonomy of the causal Phomopsis and Diaporthe

From the facts mentioned above, it might be said that Phomopsis-isolates causing the con- 

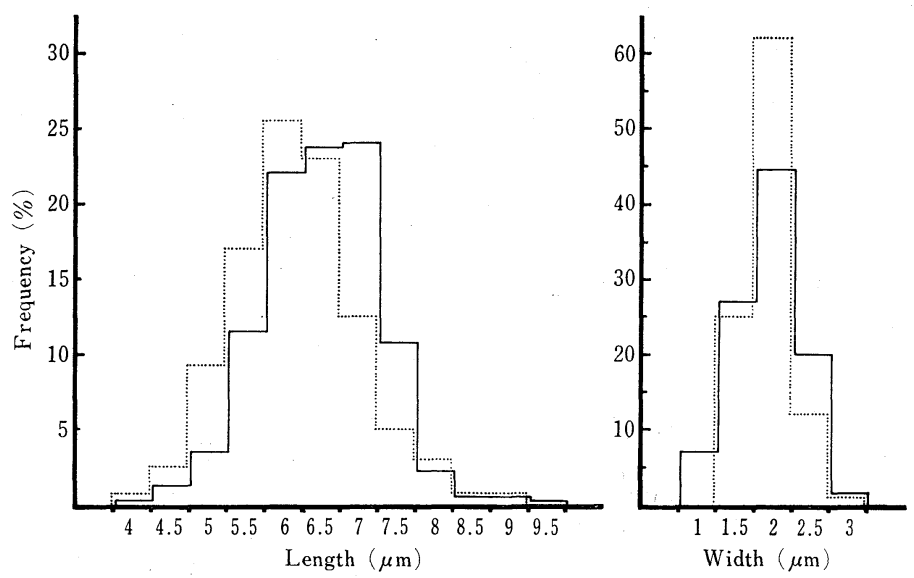

Fig. 2. Histogram of sizes of $\alpha$-conidia produced on PSA slant culture of Phomopsis-isolates from concave rot of melon fruits. (-: 600 conidia of colony groups A and B were measured; ........: 370 of groups $\mathrm{C}$ and $\mathrm{D})$.
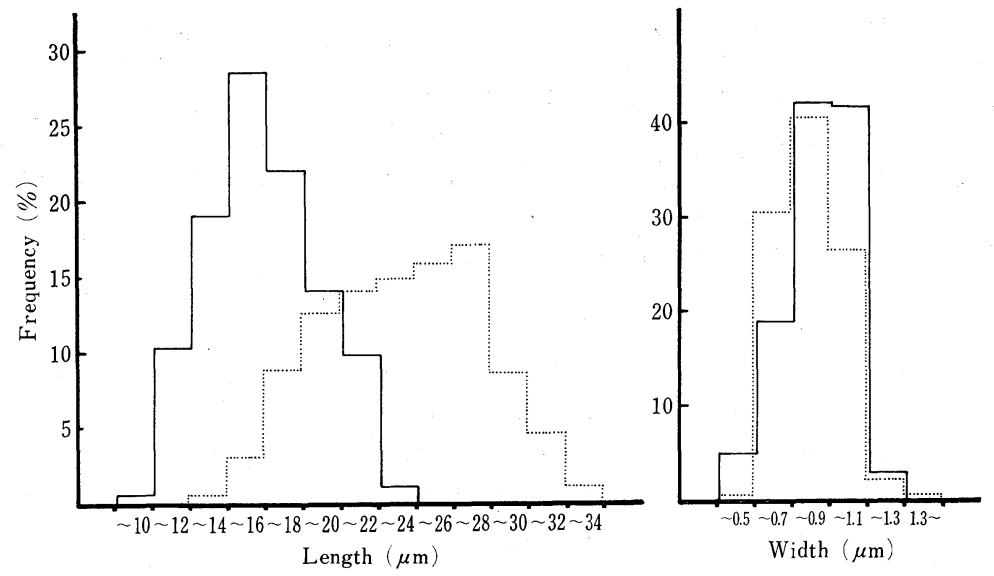

Fig. 3. Histogram of sizes of $\beta$-conidia produced on PSA slant culture of Phomopsis-isolates from concave rot of melon fruits. ( - : 558 conidia of colony groups A and B were measured; -..-... 338 of groups $\mathrm{C}$ and $\mathrm{D})$.

cave rot of melon fruit were divided into two groups based on the sizes of their $\alpha$ - and $\beta$-conidia. One is composed of the isolates listed as groups $\mathrm{A}$ and $\mathrm{B}$ in their growth type of colony, and the other is of those as groups $\mathrm{C}$ and $\mathrm{D}$. The former group of isolates has $\beta$-conidia commonly shorter than $20 \mu \mathrm{m}$ and those conidia of the latter group are longer than $20 \mu \mathrm{m}$ (Table 6).

Only a species of the genus Diaporthe, D. melonis Beraha et O'Brien 1979, has hitherto been reported to be parasitic to melon, Cucumis melo L. It has a conidial stage of Phomopsis causing soft rot of cantaloupe melon fruits. Beraha and $\mathrm{O}^{\prime} \mathrm{Brien}^{1)}$ tentatively identified it as Phomopsis cucurbitae McKeen. Perithecial stage of Diaporthe melonis was produced on a sterilized stem of Glottidium sp. and they treated this specimen as holotype of their new species.

As shown in Table 7, Figs. 3 and 4, morphological characteristics of perithecia, asci and ascospores in Japanese Diaporthe produced on agar media coincided to those of Diaporthe melonis. However, the sizes of $\beta$-conidia in Japanese Diaporthe were distinctly shorter than those of $D$. melonis. On the other hand, sizes of $\alpha$ - and $\beta$-conidia of Phomopsis-isolates belonging to cul- 
Table 7. Comparison of dimensions between Japanese ${ }^{\text {a) }}$ and North American Diaporthe fungi causing fruit rot of melon

\begin{tabular}{ccccc}
\hline Species & $\begin{array}{c}\text { Ascus }(\mu \mathrm{m}) \\
\text { (average) }\end{array}$ & $\begin{array}{c}\text { Ascospore }(\mu \mathrm{m}) \\
\text { (average) }\end{array}$ & $\begin{array}{c}\alpha \text {-conidium }(\mu \mathrm{m}) \\
\text { (average) }\end{array}$ & $\begin{array}{c}\beta \text {-conidium }(\mu \mathrm{m}) \\
\text { (average) }\end{array}$ \\
\hline Diaporthe sp. & $25 \sim 38 \times 4 \sim 6$ & $7.5 \sim 10 \times 2 \sim 3$ & $5 \sim 9 \times 2 \sim 3$ & $12 \sim 20 \times 2 \sim 1.5$ \\
(S-61) & $(32 \times 5.2)$ & $(8.6 \times 2.8)$ & $(6.9 \times 2.3)$ & $(16.5 \times 1.2)$ \\
Diaporthe sp. & $21 \sim 39 \times 3 \sim 6$ & $7.5 \sim 9 \times 2 \sim 3$ & $5.5 \sim 7.5 \times 2 \sim 2.5$ & $11 \sim 20 \times 0.5 \sim 1.2$ \\
(S-61) & $(31.4 \times 4.8)$ & $(8.3 \times 2.8)$ & $(6.6 \times 2.3)$ & $(15.3 \times 1)$ \\
Diaporthe sp. & $21 \sim 35 \times 3 \sim 5$ & $8 \sim 9.5 \times 2.5 \sim 3$ & $5 \sim 8 \times 1.5 \sim 2.5$ & $14 \sim 20 \times 1 \sim 1.2$ \\
(S-65) & $(28.4 \times 4.1)$ & $(8.5 \times 2.7)$ & $(6.4 \times 2)$ & $(16.8 \times 1.1)$ \\
Diaporthe sp. & $25 \sim 35 \times 4.5 \sim 6.5$ & $7.5 \sim 10 \times 2.5 \sim 4$ & & \\
(S-75) & $(31 \times 5)$ & $(8.9 \times 2.9)$ & & \\
D. melonis & $25 \sim 36 \times 3.5 \sim 6$ & $7 \sim 11 \times 2 \sim 4.5$ & $6 \sim 10 \times 2 \sim 3$ & $18 \sim 28 \times 1 \sim 2$ \\
& $(30.8 \times 4.8)$ & $(9.6 \times 3.1)$ & $(8.3 \times 2.6)$ & $(24.7 \times 1.3)$ \\
Phomopsis sp. & & & $4 \sim 9 \times 1 \sim 3$ & $14 \sim 34 \times 0.5 \sim 1.8$ \\
(Growth type D and C) & & $(6.2 \times 1.9)$ & $(23.8 \times 0.9)$ \\
\hline
\end{tabular}

a) All isolates of Japanese Diaporthe belonged to culture group A, b) Perithecia matured on plane agar with a fragment of melon fruit, c) Perithecia matured on PSA, d) Beraha and O'Brien (1979).

ture groups $\mathrm{C}$ and $\mathrm{D}$ were quite identical with those of the Phomopsis stage of Diaporthe melonis. Therefore, a new variety of Diaporthe melonis is proposed for the Japanese Diaporthe causing concave rot of melon fruit as D. melonis Beraha et O'Brien var. brevistylospora Kobayashi et Ohsawa. Phomopsis-isolates belonging to culture types C and D were identified as the conidial stage of Diaporthe melonis Beraha et O'Brien var. melonis, Phomopsis cucurbitae McKeen sense Beraha et $\mathrm{O}^{\prime} B$ rien. Technical description is as follows:

Diaporthe melonis Beraha et O’Brien var. brevistylospora Kobayashi et Ohsawa, var. nov.

Anamorph: Phomopsis brevistylospora Kobayashi et Ohsawa, nom. nov.

Perithecia in agaro aequaeo cum fragmentoe melonis vel in agaro sucroso-decocto tuberosi formata, saepe caespitosa, in textura carbonacea stromatica submersa; ostiola in collum elongatum producta, $0.5 \sim 2 \mathrm{~mm}$ longa; asci octospori sessile, cylindracei, ad basim attenuati, $21 \sim$ $39 \times 3 \sim 6.5 \mu \mathrm{m}$, plerumque $25 \sim 35 \times 3.5 \sim 6 \mu \mathrm{m}$, medio $30.4 \times 4.7 \mu \mathrm{m}$; ascosporae irregulariter biseriatae, hyalinae, ellipsoideae, bicellulares, $7.5 \sim 10 \times 2 \sim 4 \mu \mathrm{m}$, plerumque $8 \sim 9 \times 2.5 \sim 3$ $\mu \mathrm{m}$, medio $8.5 \times 2.7 \mu \mathrm{m}$; pycnidia numerosa irregulariter in agaro dispersa, plerumque solitaria, stromatica, ostiolata, unilocularia $150 \sim 680 \mu \mathrm{m}$ latis, $120 \sim 560 \mu \mathrm{m}$ alta; $\alpha$-conidia unicellularia, fusiformia, hyalina, $4 \sim 9.5 \times 1 \sim 3 \mu \mathrm{m} ; \beta$-conidia unicellularia, hyalina, filiformia, ad extremum unum curvata, $10 \sim 23 \times 0.4 \sim 1.3 \mu \mathrm{m}$.

Holotype: dried specimen of agar plate colony containing mature perithecia, isolates FFPRI: LFP-DB-41 (TFM: FPH-7097).

Isolates: on water agar medium containing a fragment of melon fruit, isolated from the diseased fruit of Cucumis melo L.-Asaba, Shizuoka Pref., Nov. 13, 1985, by T. Ohsawa (FFPRI: LFP-DB-41, Type culture); Osuka, Shizuoka Pref., Nov. 13, 1985, by T. Ohsawa (FFPRI: LFP-DB-42). Phomopsis state only-Fukuroi, Shizuoka Pref., Oct. 29, 1985, by T. Ohsawa (FFPRI: LFP-PB-137); Asaba, Shizuoka Pref., Nov. 13, 1985, by T. Ohsawa (FFPRI: LFPPB-140, PB-141, PB-144). All isolates listed here will be registered to MAFF in 1989.

Perithecia on water agar containing a fragment of melon fruit and on potato sucrose agar, gregarious in black stroma, with a long beak; beaks black, $0.5 \sim 2 \mathrm{~mm}$ in length; asci 8-spored, oblong, hyaline, tapering toward the end, $21 \sim 39 \times 3 \sim 6.5 \mu \mathrm{m}$, mostly $25 \sim 35 \times 3.5 \sim 6 \mu \mathrm{m}$, and $30.4 \times 4.7 \mu \mathrm{m}$ in average; ascospores irregularly biseriate, hyaline, 2-celled with a median septum, $7.5 \sim 10 \times 2 \sim 4 \mu \mathrm{m}$, mostly $8 \sim 9 \times 2.5 \sim 3 \mu \mathrm{m}$, and $8.5 \times 2.7 \mu \mathrm{m}$ in average; pycnidia irregularly 

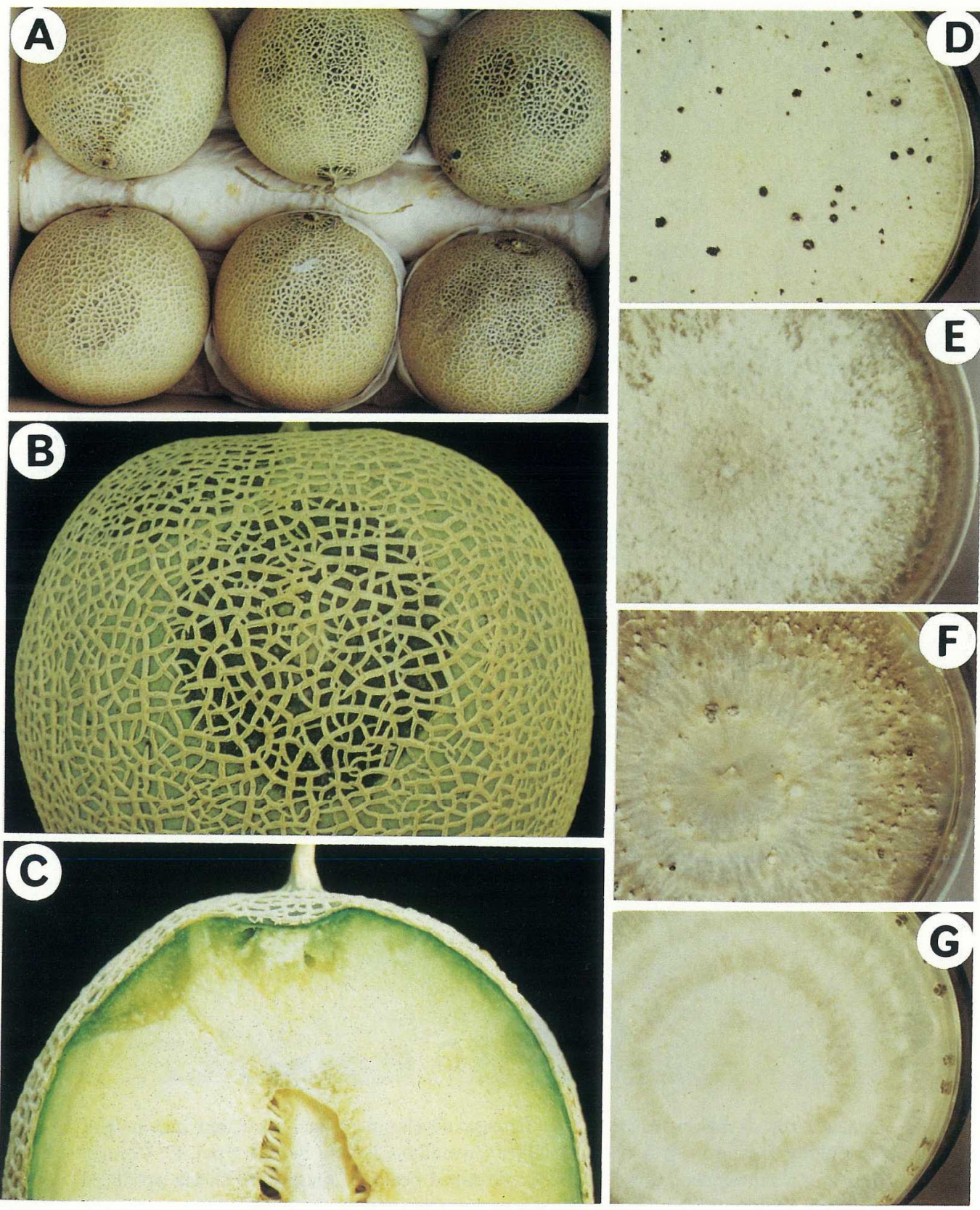

Fig. 4. Concave rot of melon fruit (1). A: Disease development on harvested melon fruits, B: Magnified symptom of the concave rot, C: Cross section of the diseased fruit showing soft rot beneath the skin, D G: Colony type of Phomopsis-isolates obtained from the diseased fruits (D: Group A, E: Group B, F: Group C, G: Group D). 

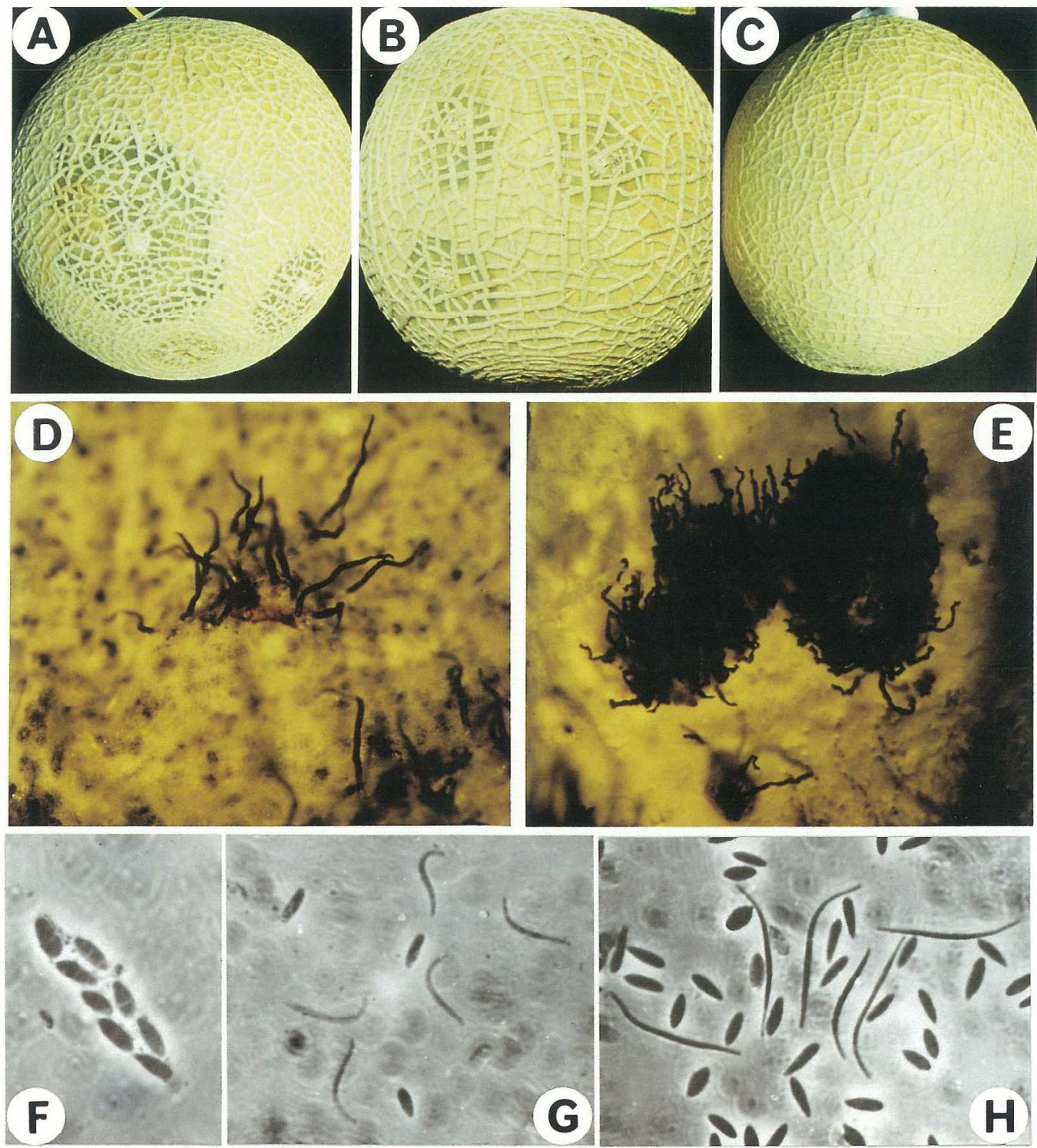

Fig. 5. Concave rot of melon fruit (2). A: Disease development on inoculated melon fruit (Inoculum: Isolate S-70, A type), B: Ditto (Inoculum: Isolate S-7, D type), C: Control (Burning wound inoculation), D and E: Grouped beaks of mature perithecia produced on PSA (Isolate S-61, A type), F: Ascus of Diaporthe melonis var. brevistylospora containing 8 ascospores (phase contrast), G: $\alpha$ - and $\beta$-conidia of Diaporthe melonis var. brevistylospora (Anamorph: Phomopsis brevistylospora), G: $\alpha$ - and $\beta$-conidia of Diaporthe melonis var. melonis (Anamorph: Phomopsis cucurbitae McKeen sensu Beraha et O'Brien). 
scattered on PSA or on sterillized vine, unilocular in stroma, 150 680 $\mu \mathrm{m}$ in diam., 120 560 $\mu \mathrm{m}$ in height; $\alpha$-conidia unicellular, fusoid, hyaline, $4 \sim 9.5 \times 1 \sim 3 \mu \mathrm{m}$, mostly $5.5 \sim 7.5 \times 1.5 \sim$ $2.5 \mu \mathrm{m}$, and $6.5 \times 1.9 \mu \mathrm{m}$ in average; $\beta$-conidia unicellular, filiform or hooked, $10 \sim 23 \times 0.4 \sim$ $1.3 \mu \mathrm{m}$, mostly $14 \sim 17 \times 0.7 \sim 1.1 \mu \mathrm{m}$, and $15.9 \times 0.9 \mu \mathrm{m}$ in average.

Phomopsis cucurbitae McKeen sensu Beraha et O'Brien, Phytopath. Z. 94: 205, 1979 (the conidial stage of Diaporthe melonis Beraha et O'Brien var. melonis)

Pycnidia irregularly scattered on PSA or on sterilized vines, unilocular in stroma; $\alpha$-conidia one-celled, fusoid, hyaline, $4 \sim 9 \times 1.5 \sim 3 \mu \mathrm{m}$, mostly $5.5 \sim 7 \times 1.5 \sim 2 \mu \mathrm{m}$, and $6.2 \times 1.9 \mu \mathrm{m}$ in average; $\beta$-conidia unicellular, hyaline, filiform or hooked, strongly curved, $14 \sim 34 \times 0.5 \sim 1.8$ $\mu \mathrm{m}$, mostly $19 \sim 28 \times 0.7 \sim 1.0 \mu \mathrm{m}$, and $23.8 \times 0.9 \mu \mathrm{m}$ in average.

Isolates: on PSA and water agar containing a fragment of melon fruit isolated from the diseased fruit of Cucumis melo L.--Mori, Shizuoka Pref., Sept. 29, 1985, by T. Ohsawa (FFPRI: LFP-PB-138); Fukuroi, Shizuoka Pref., Nov. 13, 1985, by T. Ohsawa (FFPRI: LFP-PB-139); Toyoda, Shizuoka Pref., Oct. 18, 1985, by T. Ohsawa (FFPRI: LFP-PB-142); Shizuoka Pref., Oct. 6, 1984, by T. Ohsawa (FFPRI: LFP-PB-143).

\section{Literature cited}

1. Beraha, L. and O'Brien, M.J. (1979). Phytopath. Z. 94: 199-207.

2. Ohsawa, T. and Kobayashi, T. (1988). Ann. Phytopath. Soc. Japan 54: 69 (Abstr. in Japanese).

3. Ohsawa, T., Morita, H., Furuki, I. and Suzuki, H. (1983). Ibid. 49: 397-398 (Abstr. in Japanese).

\section{和 文 摘 要}

\section{大沢高志・小林享夫 : メロンの果実腐敗を起こす新病害宿没病とその病原菌}

1981 年以来, 静岡県産のネットメロン果実に, 収穫・出荷後, 円形の淡褐色水浸状の軟腐陣没を伴ら果 実腐敗が発生し，新病害として問題となった。発生は 6 10 月出荷のものに多く，病斑上での子実体形成 はきわめてまれだが，病患部からの分離では，少数（3\%）の Fusarium 属菌を除き，圧倒的に Phomopsis 属菌が検出 $(97 \%)$ された。これらのPhomopsis 属菌の分離株は PSA 上での培養菌叢の特徴から A, B, C および D 群の 4 グループに分けられたが，いずれの群の菌株も人工接種による病徵の再現性が確認され， 病原菌であることが立証された。感染期は生育中の果実ネット形成期と考えられ，発病はほとんど収穫後 4 5 日以降である。病原菌の $\alpha$ - 拉よび $\beta$-胞子の形態調査から，これらの Phomopsis 属菌は $\beta$-胞子の大 きさにより明らかに 2 群に区別でさた。ひとつは培養群 $\mathrm{A}$ および B に属するるので， $\beta$-胞子の長さが 20 $\mu \mathrm{m}$ 以下であり，他のひとつは培養群 $\mathrm{C}$ および D に属する菌で, $\beta$-胞子の長さが $20 \mu \mathrm{m}$ 以上のものであ った。分離菌株を各種培養条件のもとで完全世代形成を試みたところ, A 群の 4 菌株が PSA 上あるいは 果皮片加用素寒天培地上で Diaporthe 世代を完熟した。これらの Diaporthe 属菌と Phomopsis 属菌の形態 的特徵を検討した結果，A 打よび B 群の Diaporthe および Phomopsis 属菌をそれぞれメロン果実上の既 知種 Diaporthe melonis Behara et O'Brien の新変種 D. melonis var. brevistylospora Kobayashi et Ohsawa と記載し，C および D 群の Phomopsis 属菌を Diaporthe melonis Beraha et O’Brien var. melonis の不完 全世代である Phomopsis cucurbitae McKeen sensu Beraha et O’Brien と同定した。 